\title{
High-resolution X-ray computed tomography of an extant new Donuea (Araneae: Liocranidae) species in Madagascan copal
}

\author{
JAN BOSSELAERS ${ }^{1}$, MANUEL DIERICK ${ }^{2}$, VEERLE CNUDDE ${ }^{2,3}$, BERT MASSCHAELE ${ }^{2}$, \\ LUC VAN HOOREBEKE ${ }^{2} \&$ PATRIC JACOBS ${ }^{3}$ \\ ${ }^{\prime}$ Section of invertebrates, Royal Museum for Central Africa, B-3080 Tervuren, Belgium. E-mail: hortipes@dochterland.org \\ ${ }^{2}$ Dept. of Subatomic and Radiation Physics, Ghent University, Proeftuinstraat 86, B-9000 Ghent, Belgium \\ ${ }^{3}$ Dept. of Geology and Soil Science, Ghent University, Krijgslaan 281/S8, B-9000 Ghent, Belgium
}

\begin{abstract}
A new extant Donuea (Liocranidae) species is described from Madagascar, from both alcohol preserved fresh material and also as a subfossil in copal from the Sambava area. X-ray micro computed tomography was used to visualise minute details of the male palp of the copal specimen in order to confirm conspecificity. This is the first time a new spider species discovered in Madagascan copal can immediately be demonstrated as belonging to an extant species.
\end{abstract}

Key words: subfossil resin, Dionycha, palp structure, collustrata, decorsei, extant, extinct, fauna, palaeontology

\section{Introduction}

Arthropod inclusions in fossilised resins, first described by Sendelius (1742), offer a unique opportunity to study past life forms in unmatched detail (Bachofen-Echt 1949; Poinar 1992). Insects and spiders enclosed in Tertiary Baltic and Dominican ambers are well known (Petrunkevitch 1942, 1958; Bachofen-Echt 1949; Wunderlich 1986, 1988, 2004, 2008; Poinar 1992; Penney 2001, 2008). Data obtained from such specimens can be an invaluable resource for improving our insight into the phylogeny of groups (Wunderlich 1986, 2004; Kathirithamby \& Grimaldi 1993; Grimaldi et al. 1997; Kotrba 2004).

However, interesting spider inclusions have also been found in the more recent copal (Wunderlich 1986, 1988). Dunlop et al. (2010) list 24 species from copal, 15 of these from Madagascar. Copal is a somewhat illdefined (Nagel \& Körnchen 1934; Vandenabeele et al. 2003; Stacey et al. 2006; Penney 2008) term for a hardened, polymerised, subfossil diterpenoid resin (Lambert \& Poinar 2002; Scalarone et al. 2003) which, contrary to amber, has not yet lost most of its volatile terpenes (Poinar 1992; Scalarone et al. 2003). On the North-East coast of Madagascar, substantial amounts of copal with inclusions are found, originating from resin of Hymenaea (= Trachylobium) verrucosa Gaertner (Langenheim 1969; Schlüter \& von Gnielinski 1987; Poinar 1992; Poinar \& Brown 2002). While amber is generally considered to be fossilized resin older than two million years (Wunderlich 1986, 1988; Poinar 1992; Ross 1998), copal is estimated by different authors to be a few hundred to four million years old, depending on its origin, i.e. of Holocene, Pleistocene or Pliocene age (Maia e Vale \& Fernandes Costa 1962; Schlee \& Glöckner 1978; Schlee 1984; Wunderlich 1986; Poinar 1992; Anderson 1997; Dubois 1998; Stankiewicz et al. 1998; Dubois \& LaPolla 1999). Madagascar copal, reported as more immature than Dominican copal (Moreno et al. 2001), is considered by some authors to be only a few decades old (Poinar 1999; Wunderlich 2004; Penney et al. 2005).

It has been stated that most, or all, of the inclusions in copal are Recent species (Poinar 1992: 63, 1999), but some inclusions have been reported as representing extinct species (Hills 1957). Lourenço (2000) described the spider species Archaea copalensis (Archaeidae) from Madagascan copal, but it was later synonymised with the extant Eriauchenius gracilicollis (Millot 1948) by Wunderlich (2004: 794). Bosselaers 
(2004) described a new Garcorops species (Selenopidae) from Madagascan copal which has not yet been found in the extant fauna. Wunderlich (2004) considered Madagascar copal as an interesting source of unknown arthropods, including spiders, because large parts of the resin-producing forests have been destroyed. He described 11 new spider species from Madagascan copal (Wunderlich 2004), none of which has been collected alive in the field to date.

The first author obtained a piece of copal from the Sambava area, north-east Madagascar, containing a male spider whose affinities were initially uncertain. Visual observation of the specimen was unsatisfactory because most of the dorsal side, including the diagnostically critical eye region could not be observed under the stereomicroscope, being obscured by a dense layer of air bubbles entrapped in the resin (Fig. 2 B, D). Detailed study of the male palps was also difficult because of cracks, air bubbles and a milky haze interfering with the transparency of the resin matrix (Fig. $2 \mathrm{G}, \mathrm{H}$ ).

Unfortunately, it is quite common that visual observation of arthropods enclosed in fossil and subfossil resins is impeded by light-reflecting cracks in the matrix, or by opaque inclusions such as dark material, air bubbles or white "mould", consisting of clouds of minute bubbles or droplets (Schlee and Glöckner 1978; Kosmowska-Ceranowicz et al. 1997). Special lighting techniques can partially overcome these problems (Petrunkevitch 1942; Schlee and Glöckner 1978), but they do not permit the observation of hidden structures. Extracting the arthropods from the matrix using solvents (Azar 1997) gives unsatisfactory results (Henderickx 2006, personal communication). Confocal laser scanning microscopy (Ascaso et al. 2003) and high-resolution X-ray computed micro-tomography (in short: 'X-ray micro-CT') (Grimaldi et al. 2000; Polcyn et al. 2002; Mayo et al. 2003; Henderickx et al. 2006; Dierick et al. 2007; Lak et al. 2008) have been used as nondestructive methods to observe resin-enclosed organisms, including spiders (Penney et al. 2007) which proved difficult to observe with classic visible light microscopy. Especially X-ray micro-CT, which, in contrast to confocal laser scanning microscopy, is not dependent on specimen autofluorescence, seems an ideal tool to observe such specimens. The technique is even suited to study the internal structure of arthropods at high resolution (Heethoff \& Norton 2009).

Previously, X-ray micro-CT had been used on our specimen and proved non-destructive to the inclusion, although it involved some trimming of the copal piece in order to obtain a sufficiently high image resolution.

Based on the first images obtained, the species was tentatively attributed to Gallieniellidae (Cnudde et al. 2006), but more detailed imaging allowed us to unequivocally attribute the species to the genus Donиea Strand 1932 (Liocranidae) (Ramírez 2009, personal communication). Examination of recent field collections of unidentified specimens in the MRAC collection turned up a male specimen belonging to the same species. Based on data derived from both male specimens, the species is described below as new.

\section{Material and methods}

$\mathrm{X}$-ray computed tomography provides three-dimensional images of the internal structure of a scanned sample, non-destructively, by calculating the X-ray attenuation within objects. To obtain the 3D information, an X-ray tomograph first records a high number of 2D radiographs of the sample taken from different angles by rotating the sample relative to the X-ray source-detector system. For this research the multi-purpose open type X-ray microCT set-up of the UGCT group of the Ghent University was used. This high-resolution X-ray CT system consists of a dual head Feinfocus ${ }^{\circledR}$ tube as an X-ray source and a Varian Paxscan 2025 flat panel detector with 600 micrometer CsI scintillator. This detector consists of 1980x1496 pixels, with a pixel size of $127 \mu \mathrm{m}$.

The rotation motor is a high-precision UPR-160 R Micos ${ }^{\oplus}$ motor with air-bearing. A XY piëzo stage (PILine ${ }^{\circledR}$ Ultra-Compact Translation Stage) is mounted on the rotation motor to centre the sample precisely to allow for maximal magnification while keeping the desired volume of interest in view at all time. In total, 1000 projections were recorded, each an average of 4 exposures of 600 milliseconds. With a source-detector distance of $890 \mathrm{~mm}$ and a source-object distance of $19 \mathrm{~mm}$ a magnification of 47 was obtained, resulting in a voxel size inside the sample of 2.7 micrometres.

The high performance in-house developed software package Octopus was used for tomographic reconstruction (Dierick et al. 2004). Because the volume of interest was significantly smaller than the total 
amber piece, a so called region-of-interest scan was recorded, implying that the outer edges of the amber piece extended outside of the recorded area. This required a specially adapted reconstruction method to deal with the truncation of the data. The 3D renderings were made with VGStudio Max (Volume Graphics, Heidelberg, Germany).

The copal piece holding the subfossil specimen was trimmed, without damaging the inclusion, to a $13 \mathrm{x} 11$ x $5 \mathrm{~mm}$ block using a belt saw in order to enable a high resolution X-ray CT to be performed on it (Fig. $2 \mathrm{~A}$ ). The piece was also polished again with fine grinding paper and polishing paste in order to allow for visual observation as well.

For visual observation, the specimens were observed, photographed and drawn under Euromex MIC 465 and Olympus SZC-X9 binocular microscopes equipped with an eyepiece grid and Fuji Finepix 2800 or Praktica DC42 digital cameras. All measurements are in $\mathrm{mm}$, unless otherwise stated. The format for leg spination follows Platnick and Shadab (1975), amended for ventral spine pairs according to Bosselaers \& Jocqué (2000). Leg spination is also illustrated in a schematic representation (Fig. 2 E) where pl, do, rl and ve sides of leg articles are flattened as a folding net (Dürer 1525; Bosselaers 2009).

Abbreviations: ACR, anterior cheliceral rim; AER, anterior eye row; ALE, anterior lateral eyes; ALS, anterior lateral spinnerets; AME, anterior median eyes; C, conductor; do, dorsal; E, embolus; fe, femur; ICS, intercoxal sclerites (Bosselaers \& Jocqué 2002: 247); lat, lateral; MA, median apophysis; MOQ, median ocular quadrangle; mt, metatarsus; pa, patella; PCR, posterior cheliceral rim; PCT, precoxal triangles (Bosselaers \& Jocqué 2002: 247, fig. 1K; Penniman 1985: 16); PER, posterior eye row; pl, prolateral; PLE, posterior lateral eyes; PLS, posterior lateral spinnerets; plv, prolateral ventral; PMS, posterior mesian spinnerets; PTA, prolateral tibial apophysis; rl, retrolateral; rlv, retrolateral ventral; RTA, retrolateral tibial apophysis; ti, tibia; ve, ventral; w, width.

Abbreviations of personal and institutional collections (curators in parentheses):

MNHN Museum Nationale d'Histoire Naturelle de Paris (Christine Rollard)

MRAC Royal Museum for Central Africa, Tervuren (Rudy Jocqué)

\section{Taxonomy}

Donuea collustrata Bosselaers \& Dierick sp. nov.

Figs. 1 A-E; 2 A-F; 3 A-M; 4 A-I.

Type material. Holotype male: Madagascar, Foulpointe, forest on clay soil, beating vegetation, July 1995, A. Pauly leg. (MRAC 206172). Paratype male, in copal from the Sambava area, NE Madagascar, MRAC.

Diagnosis. The species can be distinguished from the type species Donuea decorsei Simon, 1903, by its bifid RTA as opposed to a simple one (Simon 1903: 138), its large, bifurcated MA, a simple, pointed conductor situated ventrally instead of dorsally of MA and its shorter embolus which does not describe a circular loop before passing behind the tegulum (Figs. 1 F, 4 C, F, I).

Description. Body length without chelicerae (holotype): 4.34, with chelicerae: 5.76. Carapace length: 1.81; w: 1.55, oval, yellow brown, darker in eye region, and with two brown lateral bands (Fig. 1 A-B, D). Fovea short and deep, pale brown, length 0.08, anterior end 1.14 from front. Eight eyes in two rows, ringed with black, AER w: 0.82, recurved from above, slightly procurved from front, PER w: 0.89, procurved from above, strongly procurved from front (Figs. $1 \mathrm{~A}, \mathrm{D}, 3 \mathrm{M}$ ). MOQ depth: 0.32, anterior w: 0.37, posterior w: 0.42. All eyes subequal, ALE oval, others circular. All four median eyes with dark retina restricted to median 2/3. Anterior median eyes slightly closer to each other than to ALE. Eyes of PER equidistant, separated by about twice their diameter. ALE and PLE touching, on common tubercle. Clypeus vertical, 1/3 of diameter of AME. Chilum orange-brown, sclerotised, split (Fig. 3 M). Chelicerae large, yellow brown, elongated and pointing forward, parallel to the longitudinal axis of the body (Figs. 1 A-D, 2 C, F, 3 A). One large kneeshaped seta and a row of long, curved setae on ACR, cheliceral fangs brown. Six teeth on ACR, largest one 

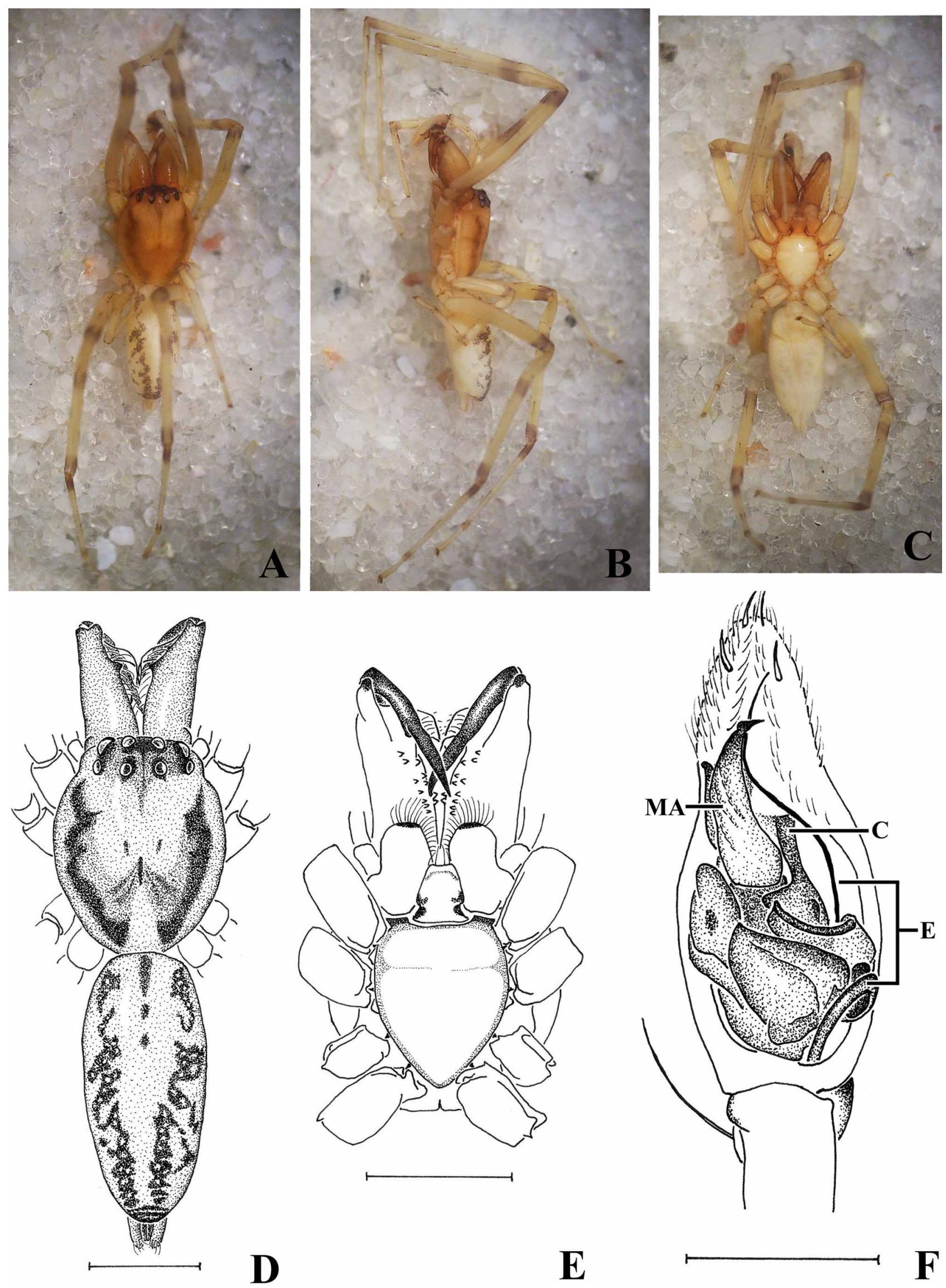

FIGURE 1 A-E. Donuea collustrata sp. n., holotype. F. Donuea decorsei, holotype, MNHN. A, habitus, do; B, habitus, lat.; C, habitus, ve; D, body, do; E, prosoma, ve; F, left male palp, ve. Scale bars: D, E: 1.0; F: 0.5. 

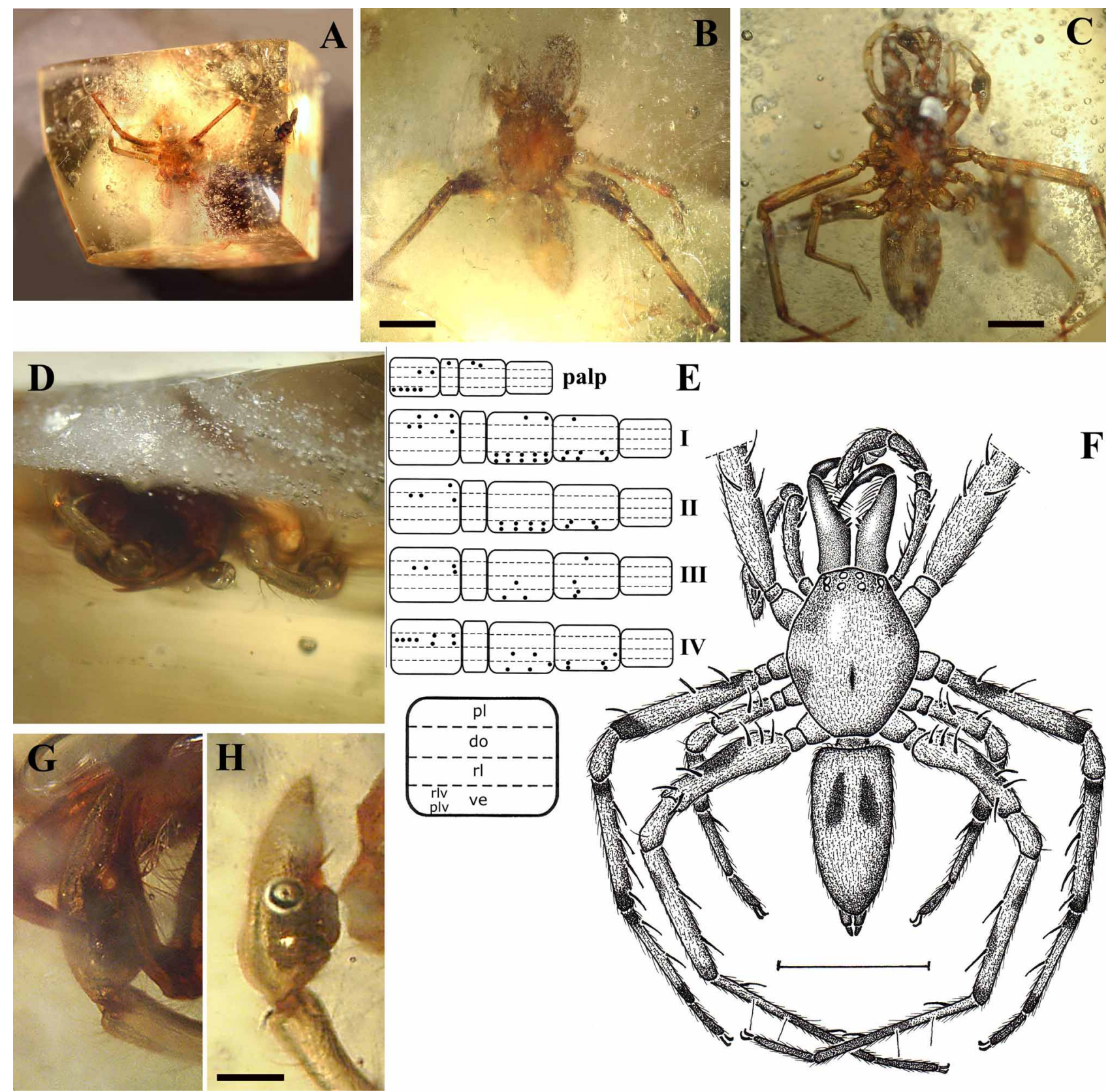

$\mathbf{F}$

FIGURE 2 A-H. Donuea collustrata sp. n. A, copal piece holding specimen, after trimming; B, copal preserved specimen, do; C, copal specimen, ve; D, frontal view of copal specimen, showing opaque layer of air bubbles; E, leg spination scheme of holotype, legend of unfolded article below; F, copal specimen, reconstruction of habitus, do; G, right male palp of copal specimen, rl; H, left male palp of copal specimen, pl. Scale bars: B, C: 1.0; F: 1.5; H: 0.25.

closest to fang base, followed by an isolated very small tooth and two pairs of small teeth separated by a small distance. Seven teeth on PCR, a pair of medium sized teeth close to fang base, followed at some distance by five small teeth in a row. Sternum length: 1.05; w: 0.95, smooth, yellow, elongated and shield-shaped, with pale broad and blunt ICS between legs I-II and II-III, and thin, brown and pointed PCT facing all coxae (Fig. 1 C, E). Pleural bars (Bosselaers \& Jocqué 2002: 247, fig. 1P; Simon 1892: 11, fig. 29) yellow-brown continuous strips, weakly protruding between coxae. Labium brown, subtrapezoidal, as long as it is wide at its base, with white, thickened anterior rim. Endites subrectangular, with apical hair tuft and serrula, no oblique depression (Fig. 1 C, E). Abdomen cream, unicolorous ventrally and with two lateral, purple brown bands dorsally (Fig. 1 A-B, D). ALS contiguous, conical, with short, blunt apical segment. PMS very thin and slender, PLS subcylindrical, mottled with grey, with pale, rounded apical segment (Figs. 1 B-D, 3 A). Legs yellow, fe, ti and mt ringed with grey basally and/or terminally (Figs. 1 A-C, 2 B-C, F). No trochanter notch, 


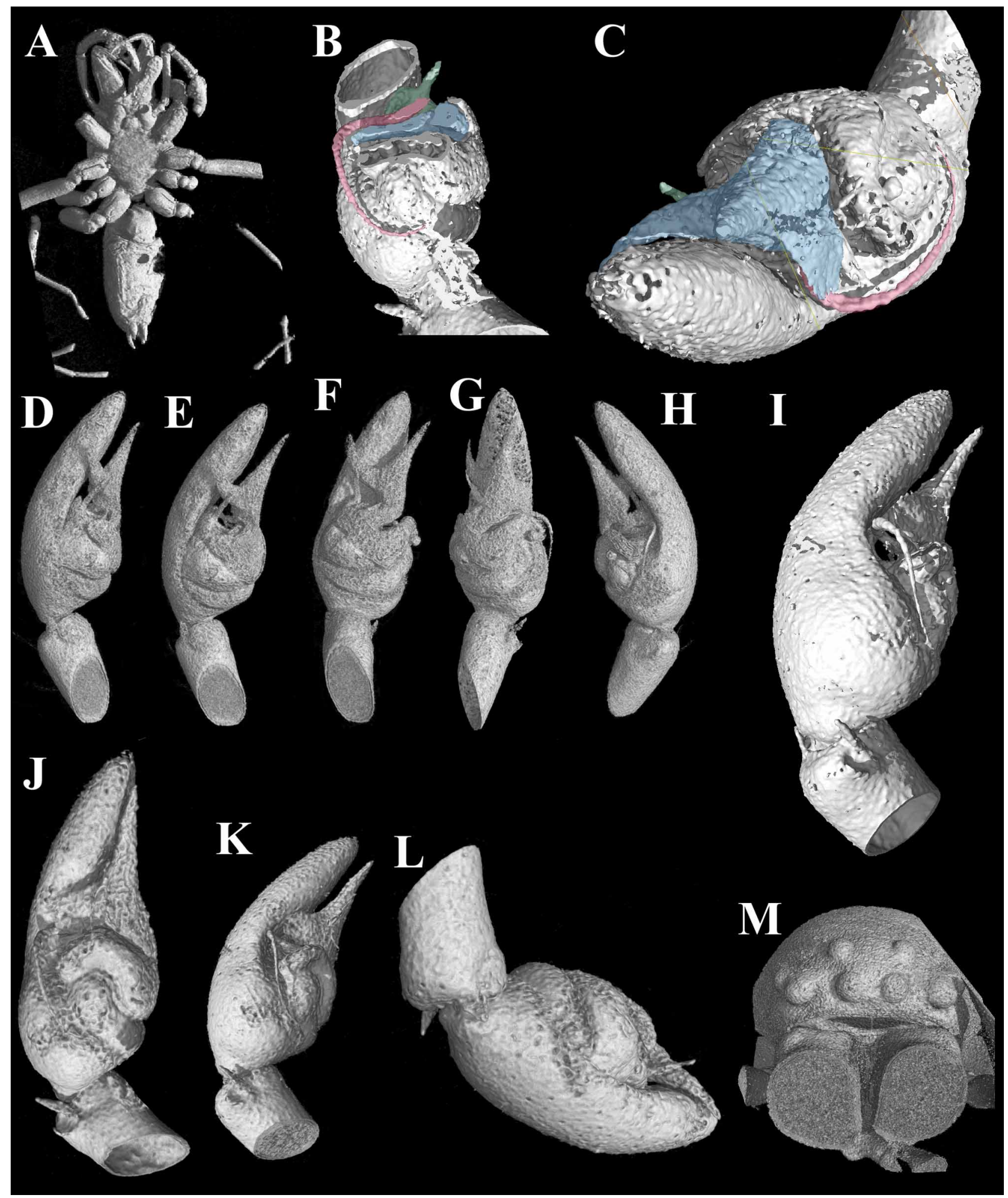

FIGURE 3 A-M. Donuea collustrata sp. n., copal specimen, X-ray CT images. A, habitus, ve; B, transversal section of right male palp, showing conductor (green) and embolus (pink) originating from behind MA (blue); C, frontal view of right male palp, colour coding as in $\mathrm{B}$; D, left male palp, pl; E, left male palp, pl-ve; F, left male palp, ve; G, left male palp, rl-ve; H, left male palp, rl; I, right male palp, rl-do view, showing embolus, PTA and RTA; J, right male palp, rl-ve, showing bifid RTA; K, right male palp, rl; L, caudal view of right male palp, showing RTA (left) and PTA (right); M, frontal view of eye region, chilum artificially darkened. 

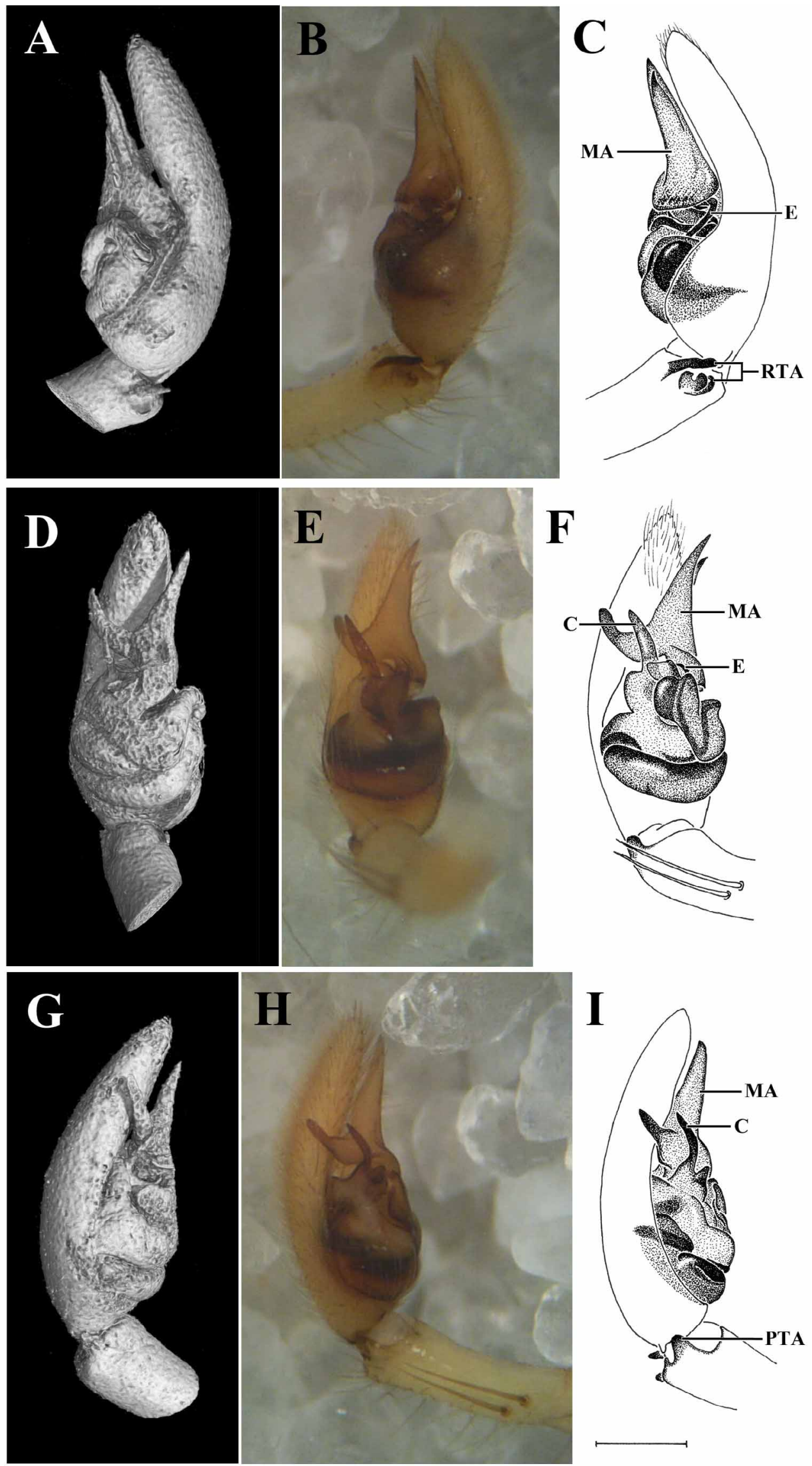

FIGURE 4 A-I. Donuea collustrata sp. n., male palp. A-C, rl; D-F, ve; G-I, pl; A, D, G, X-ray CT images of right palp of copal specimen, inverted; B, E, H, stereomicroscope photographs of left palp of holotype; C, F, I, drawings of left palp of holotype. Scale bar: 0.25 . 
no retrocoxal hymen (Raven 1998; Bosselaers \& Jocqué 2002), patellar indentation long and narrow, 3/4 of pa length. Metatarsi III and IV with sparse ve terminal preening brush. Tarsi with two claws and dense claw tufts. Leg formula 1423. Leg spination (Fig. 2 E): fe: palp do 0-1-1 rlv 1-1-1-1-1-0; I pl 0-1-1-1 do 0-1-1-1; II pl 00-0-1 do 0-1-1-1; III do 0-1-1-2; IV do 1-1-1-1-2-2; pa: palp pl 1; ti: palp pl 2-0-0; I pl 0-1-1 ve 2-2-2-2-2; II ve 2-2-2-2; III rl 0-1-0 plv 1-1-0; IV rl 0-1-1-0 plv 1-1-0 rlv 0-0-1; mt: I pl 1-0-0 ve 2-2-2; II ve 2-2-0; III pl 01-0 rl 1-0-0 ve 2-0-0; IV rl 0-0-1 ve 2-0-2.

Male palp with a simple, blunt PTA (Figs. 3 D, E, L, 4 F, I) and a bifid RTA consisting of a long, pointed do part and a cup-shaped ve part (Figs. 3 I, J, K, L, 4 A-C). Palpal tarsus elongated and piriform, with a large, bifid, flag-shaped MA (Figs. 3 C-F, 4 D-I), a simple, blunt-tipped conductor situated ventrally of the pl branch of the MA (Figs. 3 C-F, L, 4 D-I) and a long embolus emerging from below the rl branch of the MA, proceeding basally and subsequently passing behind the tegulum (Figs. $3 \mathrm{~B}-\mathrm{C}, \mathrm{G}-\mathrm{K}, 4 \mathrm{~A}-\mathrm{C}, \mathrm{F}$ ).

Female. Unknown.

Etymology. The species epithet collustrata, irradiated, refers to the X-ray tomography technique used as an aid in the description of the present species.

Remarks. The specimen preserved in copal clearly is conspecific with the field-captured holotype. It has the same size (body length 4.21) and general morphology, and both specimens are identical with respect to a number of diagnostic details. Leg spination of the copal specimen is identical to the holotype although a few spines are missing, probably having been lost when the animal got caught in the sticky resin (Figs. 2 E-F). The copal specimen has lost most of its original colour, the abdomen being partly transparent and showing two dark spots in the anterior half, presumably corresponding with the book lungs. However, the leg annulations have been mostly preserved and coincide with those of the field-captured animal (Figs. 1 A-C, 2 B, C, F). Most significantly, palpal structure of both specimens is identical in minute detail, as can be proven by juxtaposing stereomicroscope observations of the field-captured holotype with X-ray micro-CT scans of the copal preserved specimen (Fig. 4 A-I).

The assignment of Donuea to Liocranidae is debatable, and it can indeed be argued that the genus would be better placed in Clubionidae. However, a formal transfer is outside the scope of the present contribution.

\section{Discussion}

The debate whether or not arthropod inclusions in subfossil copal resins may represent extinct species is still ongoing. Although a number of copal-preserved arthropods have been attributed to extant species (Poinar 1992, 1999; Lourenço 2000), several others have not been captured in the field to date (Bosselaers 2004; Wunderlich 2004). These might be either extinct species or extant ones not yet discovered in their natural habitat (Hills 1957). Tree resin can indeed function in a way similar to a trunk eclector trap (Dubois \& LaPolla 1999), a capture method which is reputed for producing specimens of species seldom captured otherwise (Simon 1995).

Here, for the first time, a new spider species discovered in Madagascan copal can immediately be proven to be an extant one by carefully comparing stereomicroscopic observations of a field capture with X-ray micro-CT scans of the animal preserved in copal.

Hopefully, this technique will allow to link more spider specimens from Madagascar copal with extant species. The genus Eriauchenius O.P.-Cambridge 1881, for example, would be a good candidate for such a study as it is often found in Madagascar copal (Wunderlich 2004), and is known from many extant species (Wood 2008).

\section{Acknowledgements}

The authors are indebted to Martín Ramírez for first recognising the copal specimen as belonging to Donuea, to Alexandre Bonaldo for fruitful discussions, to Friedrich von Gnielinski for sending a personally reformatted and edited version fo his 1987 paper on copal, to the referees David Penney and Charles haddad 
for skilled comments that helped improve the manuscript, to Rudy Jocqué (MRAC) for the loan of field captured specimens from Madagascar, to Christine Rollard (MNHN) for the loan of the holotype of Donuea decorse $i$ and to Mark Bosselaers for trimming the copal specimen to size.

\section{References}

Anderson, K.B. (1997) The nature and fate of natural resins in the geosphere - VII. A radiocarbon (14C) age scale for description of immature natural resins: an invitation to scientific debate. Organic geochemistry, 25(3/4), 251-253.

Ascaso, C., Wierzchos, J., Carmelo Corral, J., Lopez, R. \& Alonso, J. (2003) New applications of light and electron microscopic techniques for the study of microbiological inclusions in amber. Journal of Paleontology, 77(6), 11821192.

Azar, D. (1997) A new method for extracting plant and insect fossils from Lebanese amber. Palaeontology, 40(4), 10271029.

Bachofen-Echt, A. (1949) Der Bernstein und seine Einschlüsse. Springer Verlag, Wien, 204 pp.

Bosselaers, J. (2004) A new Garcorops species from Madagascar copal (Araneae : Selenopidae). Zootaxa, 445, 1-7.

Bosselaers, J. (2009) Studies in Liocranidae (Araneae) : redescriptions and transfers in Apostenus Westring and Brachyanillus Simon, as well as description of a new genus. Zootaxa, 2141, 37-55.

Bosselaers, J. \& Jocqué, R. (2000) Studies in Corinnidae: transfer of four genera and description of the female of Lessertina mutica Lawrence 1942. Tropical Zoology, 13, 305-325.

Bosselaers, J. \& Jocqué, R. (2002) Studies in Corinnidae: cladistic analysis of 38 corinnid and liocranid genera, and transfer of Phrurolithinae. Zoologica Scripta, 31, 241-270.

Cnudde, V., Bosselaers, J., Masschaele, B., Vlassenbroeck, J., Dierick, M., Van Hoorebeke, L. \& Jacobs, P. (2006) Species description of fossil spiders supported by non-destructive high-resolution X-ray CT. Geophysical Research Abstracts, 8, 08351.

Dierick, M., Masschaele, B. \& Van Hoorebeke, L. (2004) Octopus, a fast and user-friendly tomographic reconstruction package developed in LabView. Measurement Science and Technology, 15, 1366-1370.

Dierick, M., Cnudde, V., Masschaele, B., Vlassenbroeck, J., Van Hoorebeke, L. \& Jacobs, P. (2007) Micro CT of fossils preserved in amber. Nuclear instruments \& methods in physics research. Section A - Accelerators, spectrometers, detectors and associated equipment, 580(1), 641-643.

Dubois, M. (1998) The first fossil Dorylinae with notes on fossil Ecitoninae (Hymenoptera: Formicidae). Entomological News, 109(2), 136-142.

Dubois, M. \& LaPolla, J. (1999) A preliminary review of Colombian ants (Hymenoptera: Formicidae) preserved in copal. Entomological News, 110(3), 162-172.

Dunlop, J. A., Penney, D. \& Jekel, D. (2010) A summary list of fossil spiders. In Platnick, N. I. (ed.) The world spider catalog, version 10.5. American Museum of Natural History, online at http://research.amnh.org/entomology/spiders/ catalog/index.html (7 February 2010).

Dürer, A. (1525) Underweysung der Messung mit den Zirckel, und Richtscheyt, in linien, ebnen und gantzen Corporen. Hieronymus Andreas Formschneider, Nuremberg, 178 pp. Available from: http://digital.slub-dresden.de/fileadmin/ data/27778509X/27778509X_tif/jpegs/27778509X.pdf (25 November 2009).

Grimaldi, D., Agosti, D. \& Carpenter, J.M. (1997) New and rediscovered primitive ants (Hymenoptera : Formicidae) in Cretaceous amber from New Jersey, and their phylogenetic relationships. American Museum Novitates, 3208, 1-43.

Grimaldi, D., Nguyen, T. \& Ketcham, R. (2000) Ultra-High-Resolution X-ray Computed Tomography (UHR CT) and the study of fossils in amber. 77-91. In Grimaldi, D. (ed). Studies on fossils in amber, with particular reference to the Cretacaous of New Jersey. Backhuys Publishers, Leiden.

Heethoff, M. \& Norton, R. (2009) A new use for synchrotron X-ray microtomography: three-dimensional biomechanical modeling of chelicerate mouthparts and calculation of theoretical bite forces. Invertebrate Biology, 128(4), 332-339.

Henderickx, H., Cnudde, V., Masschaele, B., Dierick, M., Vlassenbroeck, J. \& Van Hoorebeke, L. (2006) Description of a new fossil Pseudogarypus (Pseudoscorpiones: Pseudogarypidae) with the use of X-ray micro-CT to penetrate opaque amber. Zootaxa, 1305, 41-50.

Hills, E.S. (1957) Fossiliferous Tertiary resin from Allendale, Victoria. Proceedings of the Royal Society of Victoria, 69, $15-19$.

Kathirithamby, J. \& Grimaldi, D. (1993) Remarkable stasis in some Lower Tertiary parasitoids: descriptions, new records, and review of Strepsiptera in the Oligi-Miocene amber of the Dominican Republic. Entomologica scandinavica, 24, 31-41.

Kosmowska-Ceranowicz, B., Pielinska, A., Kulicka, R., Leciejewicz, K., Kwiatowska, K. \& Gierlowski, W. (1997) Bursztyn, skarb dawnych morz. 2nd. ed. Sadyba, Warszawa, 30 pp.

Kotrba, M. (2004) Baltic amber fossils reveal early evolution of sexual dimorphism in stalk-eyed flies (Diptera: 
Diopsidae). Organisms, Diversity \& Evolution, 4, 265-275.

Lak, M., Neraudeau, D., Nel, A., Cloetens, P., Perrichot, V. \& Tafforeau, P. (2008) Phase contrast X-ray synchrotron imaging: opening access to fossil inclusions in opaque amber. Microscopy and microanalysis, 14(3), 251-259.

Lambert, J.B. \& Poinar, G.O. (2002) Amber: the organic gemstone. Accounts of Chemical Research, 35, $628-636$.

Langenheim, J. (1969) Amber: a botanical inquiry. Science, 163, 1157-1169.

Lourenço, W. (2000) Premier cas d'un sub-fossile d'araignée appartenant au genre Archaea Koch \& Berendt (Archaeidae) dans le copal de Madagascar. Comptes rendus de l'Académie des sciences, Paris, Séries IIA, 330(7), 509-512.

Maia e Vale, M. \& Fernandes Costa, A. (1962) Contribuiçâo para o estudo da goma copal de Angola. Boletim da Escola de Farmácia da Universidade de Coimbra, Ediçao científica, 22, 94-112.

Mayo, S., Davis, T., Miller, P., Paganin, D., Pogany, A., Stevenson, A. \& Wilkins, S. (2003) X-ray phase-contrast microscopy and microtomography. Optics Express, 11(19), 2289-2302.

Moreno, Y., Christensen, D. \& Nielsen, O. (2001) A NIR-FT-Raman study of fossilized resins from the Dominican Republic, Mexico and Madagascar. Asian Chemistry Letters, 5(3), 117-123.

Nagel, W. \& Körnchen, M. (1934) Untersuchung über Kopale. Wissenschaftliche Veröffentlichungen aus dem SiemensKonzern, 13(3), 42-51.

Penney, D. (2001) Advances in the taxonomy of spiders in Miocene amber from the Dominican Republic (Arthropoda: Araneae). Palaeontology, 44(5), 987-1009.

Penney, D. (2008) Dominican amber spiders. Siri Scientific Press, Manchester, 178 pp.

Penney, D., Ono, H. \& Selden, P.A. (2005) A new synonymy for the Madagascan copal spider fauna (Araneae, Selenopidae). Journal of Afrotropical Zoology, 2, 41-44.

Penney, D., Dierick, M., Cnudde, V., Masschaele, B., Vlassenbroeck, J., Van Hoorebeke, L. \& Jacobs, P. (2007) First fossil Micropholcommatidae (Araneae), images in Eocene Paris amber using X-ray Computed Tomography. Zootaxa, 1623, 47-53.

Penniman, A. (1985) Revision of the britcheri and pugnata groups of Scotinella (Araneae, Corinnidae, Phrurolithinae) with a reclassification of phrurolithine spiders. Columbus: The Ohio State University, PhD dissertation, available through University Microfilms International ( $\left.{ }^{\circ} 8510623\right)$.

Petrunkevitch, A. (1942) A study of amber spiders. Transactions of the Connecticut Academy of Arts and Sciences, 34, 119-464, pls 1-69.

Petrunkevitch, A. (1958) Amber spiders in European collections. Transactions of the Connecticut Academy of Arts and Sciences, 41, 97-400.

Platnick, N.I. \& Shadab, M.U. (1975) A revision of the spider genus Gnaphosa (Araneae, Gnaphosidae) in America. Bulletin of the American Museum of Natural History, 155, 1-66.

Poinar, G.O. (1992) Life in amber. Stanford University Press, Stanford, 350 pp.

Poinar, G.O. (1999) Cenozoic fauna and flora in amber. Estudios del Museo de Ciencias Naturales de Álava, 14(Núm. Espec. 2), 151-154.

Poinar, G.O. \& Brown, A.E. (2002) Hymenaea mexicana sp. nov. (Leguminosae: Caesalpinioideae) from Mexican amber indicates Old World connections. Botanical Journal of the Linnean Society, 139(2), 125-132.

Polcyn, M.J., Rogers, J.V. II, Kobayashi, Y. \& Jacobs, L.L. (2002) Computed tomography of an Anolis lizard in Dominican amber: systematic, taphonomic, biogeographic, and evolutionary implications. Paleontologia Electronica, 5(1), 1-13.

Raven, R. (1998) Revision of the Australian genera of the Miturgidae with a preview of their relationships. In: XIVth International Congress of Arachnology, Abstracts, p. 31.

Ross, A. (1998) Amber. The natural time capsule. The Natural History Museum, London, 73 pp.

Sendelius, N. (1742) Historia succinorum corpora aliena involentium et naturae opere pictorum et caelatorum ex Regiis Avgvstorvm cimeliis Dresdae Conditis aeri inscvlptorum. Jo. Friedrich Gleditsch, Leipzig, 328 pp., 13 pls.

Scalarone, D., van der Horst, J., Boon, J.J. \& Chiantore, O. (2003) Direct-temperature mass spectrometric detection of volatile terpenoids and natural terpenoid polymers in fresh and artificially aged resins. Journal of Mass Spectrometry, 38, 607-617.

Schlee, D. (1984) Notizen über einige Bernsteine und Kopale aus aller Welt. Stuttgarter Beiträge zur Naturkunde Serie $C, 18,29-37$.

Schlee, D. \& Glöckner, W. (1978) Bernstein. Bernsteine und Bernstein-Fossilien. Stuttgarter Beiträge zur Naturkunde Serie $C, 8,1-72$.

Schlüter, T. \& von Gnielinski, F. (1987) The East African Copal, its geologic, stratigraphic, palaeontologic significance and comparison with fossil resins of similar age. Occasional Paper, National Museums of Tanzania, 8, 1-32.

Simon, E. (1892) Histoire Naturelle des Araignées. Tome 1. Roret, Paris. 1084 pp.

Simon, E. (1903) Descriptions d'arachnides nouveaux de Madagascar, faisant partie des collections du Muséum. Bulletin du Muséum d'histoire naturelle de Paris 9, 133-140.

Simon, U. (1995) Untersuchungen der Stratozönosen von Spinnen und Weberknechten (Arachn.: Araneae, Opilionida) 
an der Waldkiefer (Pinus sylvestris L.). Wissenschaft und Technik Verlag, Berlin, 142pp.

Stacey, R., Cartwright, C. \& McEwan, C. (2006) Chemical characterization of ancient mesoamerican 'copal' resins: preliminary results. Archaeometry, 48(2), 323-340.

Stankiewicz, B., Poinar, H., Briggs, D., Evershed, R. \& Poinar, G. (1998) Chemical preservation of plants and insects in natural resin. Proceedings of the Royal Society of London, Series B, 264, 641-647.

Strand, E. (1932) Miscellanea nomenclatorica zoologica et palaeontologica, III. Folia zoologica et hydrobiologica 4, 133-147.

Vandenabeele, P., Grimaldi, D., Edwards, H. \& Moens, L. (2003) Raman spectroscopy of different types of Mexican copal resins. Spectrochimica Acta Part A, 59, 2221-2229.

Wood, H. (2008) A revision of the assassin spiders of the Eriauchenius gracilicollis group, a clade of spiders endemic to Madagascar (Araneae: Archaeidae). Zoological Journal of the Linnean Society, 152, 255-296.

Wunderlich, J. (1986) Spinnenfauna gestern und heute. Erich Bauer Verlag bei Quelle \& Meyer, Wiesbaden, 283 pp.

Wunderlich, J. (1988) Die fossile Spinnen im Dominikanischen Bernstein. Beiträge zur Araneologie, 2, 1-378.

Wunderlich, J. (2004) Fossil spiders in amber and copal. Beiträge zur Araneologie, 3A, 1-850.

Wunderlich, J. (2008) Fossil and extant spiders (Araneae). Beiträge zur Araneologie, 5, 1-870. 